\title{
ĐĂC ĐIỂM LÂM SÀNG, CÂ̂N LÂM SÀNG VÀ NộI SOI RUỘT NON BÓNG KÉP Ở BỆNH NHÂN XUẤT HUYẾT TIÊU HOÁ ĐẠI THỂ TẠI RUỘT NON
}

\section{TÓM TẮT}

Xuất huyết tiêu hoá $(\mathrm{XHTH})$ đại thể tai ruột non (RN) là bệnh lý hiếm gặp, việc mô tả triệu chứng cácbệnh nhân (BN) này là rất hữu ích trong lâm sàng. Mục tiêu: nghiên cứu tiến hành với mục tiêu mô tả đặc điểm lâm sàng và cận lâm sàng $\mathrm{BN}$ XHTH đại thể tại RN. Phương pháp nghiên cứu: mô tả cắt ngang. Kết quả: trên $84 \mathrm{BN}$ XHTH tại RN thấy tỷ lệ nam/ nữ là $1,96 / 1$, tuổi trung bình $B N$ nam thấp hơn nữ và có sự khác biệt về nguyên nhân XHTH theo giới. 39,3\% BN có tiền sử XHTH không rõ nguyên nhân, 35,7\% mắc bệnh mạn tính và $7,1 \%$ dùng thuốc chống đông và NSAIIDs. BN đại tiện phân đen có tỷ lệ tổn thương nằm ởtá hỗng tràng là $70,9 \%$, cao hơn so với phân máu là $37,9 \%$. BN có biểu hiện thiếu máu vừa và nặng trên lâm sàng là $38,1 \%$ và trên xét nghiệm hemoglobin là $82,1 \% .81,0 \%$ BN phải truyên khối hồng cầu. Chụp ccắt lớp vi tính phát hiện tổn thương RN ở 37,5\% BN. Kết luân: BN XHTH đại thể tại RN đa phân có mất máu vừa đến nặng và đòi hỏi phải truyền máu.

Tư khoá: xuất huyết tiêu hoá đại thể, xuất huyết tiêu hoá tai ruột non

Danh muc viết tắt: $\mathrm{BN}$ : bệnh nhân; NS: nội soi; NSRNBK: nội soi ruột non bóng kép; RN: ruột non; XHHT: xuất huyết tiêu hoá.

\section{SUMMARY}

\section{CLINICAL AND SUBCLINICAL CHARACTERISTICS OF PATIENTS WITH OVERT SMALL INTESTINAL BLEEDING}

Overt small intestinal bleeding is a rare disease and the description of clinical characteristics of patient with this disease is very useful in clinical practice. Objective: This study was conducted with the objective: to describe the clinical and subclinical characteristics of patients with overt small intestinal bleeding. Method: progression description analysis. Results: Among 84 patients, the male/ female ratio was $1.96 / 1$, the mean age of male patients was lower than that of female patients and there was a difference in the causes of bleeding by gender. There were $39.3 \%$ of patients with history of GI bleeding of unknown cause, $35.7 \%$ of patients with chronic diseases and $7.1 \%$ of patients taking anticoagulants and NSAIDs. In patients with black stools, the rate of

\footnotetext{
${ }^{1}$ Trung tâm Tiêu hoá, Gan Mật, Bệnh viện Bạch Mai

${ }^{2}$ Trường Đại học Y Hà Nội

Chiu trách nhiệm chính: Nguyễn Hoài Nam

Email: namthbm@gmail.com

Ngày nhân bài: 2.7.2021
}

Ngày phản biên khoa học: 27.8.2021

Ngày duyệt bài: 3.9.2021
Nguyễn Hoài Nam ${ }^{1}$, Đào Văn Long ${ }^{2}$, Nguyễn Công Long ${ }^{1}$, Vũ Trường Khanh ${ }^{1,2}$

lesions located in the distal duodenum and jejunum was $70.9 \%$, higher than that of blood stool at $37.9 \%$. Patients with moderate and severe blood loss on clinical manifestations accounted for $38.1 \%$ and on hemoglobin test accounted for $82.1 \%$. There were $81.0 \%$ of patients requiring red blood cells transfusion. Computed tomography detected small intestinal lesions in $37.5 \%$ of patients. Conclusion: most patients with overt small intestinal bleeding had moderate to severe blood loss and required blood transfusion.

Keywords; overt gastro-intestinal bleeding, small intestinal bleeding

\section{I. ĐĂT VẤN ĐỀ}

Xuất huyết tiêu hoá (XHTH) tại ruột non (RN) là bệnh lý hiếm gặp $(5 \% \mathrm{XHTH})$, trước đây rất khó chẩn đoán vì nội soi (NS) không tiếp cận được[1],[2]. NS RNnói chung, trong đónS RN bóng kép (NSRNNK) là phương pháp được áp dụng rộng rãi nhất, đã giúp xác định nguyên nhân cho khoảng $>80 \%$ các bệnh nhân (BN) này. Kĩ thuât này mới được áp dung tai BV Bach Mai từ 2014. Viêc mô tả triệu chứng của BN ở Viêt Nam là rất hữu ích vì cung cấp các đặc điểm giúp hướng đến chẩn đoán và xử trí đúng cho người bênh. Do đó, nghiên cứu này được tiến hành nhằm mục tiêu: Mô tả đặc điểm lâm sàng và cận lâm sàng bệnh nhân XHTH đại thể tại RN được chẩn đoán bằng NSRNBK.

\section{II. ĐỐl TƯƠNG VÀ PHƯƠNG PHÁP NGHIÊN CỨU}

Đối tượng nghiên cứu. Các BN XHTH đại thể nghi tại RN, theo Hội tiêu hoá Hoa Kỳ là BN có 2 đặc điểm sau: (1) lẩm sàng có đại tiện phân đen hoặc phân máu và (2) không thây nguyên nhân gây XHTH khiNS tiêu hoá trên và dưới, hoặc có bằng chứng chảy máu từ RN qua NSRN viên nang hoặc NS tiêu hoá trên thây máu từ hỗngtràng trào ngược lên.

BN được làm NSRNBK và chụp MSCT ổ bụng. $B N$ phát hiện tổn thương nằm ở đoạn RN từ dưới papilla đến hết hồi tràng, đáp ứng được 1 trong 3 tiêu chuẩn dưới dây sẽ được chẩn đoán là $\mathrm{XHTH}$ tại RN và lấy vào nghiên cứu:

1. Tổn thương đang chảy máu khi làm NSRNBK hoặc đã cầm chảy máu nhưng tại thời điểm chụp MSCT có thoát thuốc ra lòng RN hoặc phẫu thuật thấy chảy máu.

2. Tổn thương có dấu hiệu mới chảy máu đã 
tạm cầm, là tổn thương có cục máu đông bám, lộ điểm mạch hoặc có máu ở đoạn RN quanh tổn thương.

3. Tổn thương đã cầm chảy máu, đáp ứng tiêu chuẩn được coi là nguyên nhân XHTH RN xác định theo Shinozaki và CS[1].

Bảng 1: Tiêu chuẩn xác định nguyên nhân gây XHTH tại RN cho các tôn thương đã cầm chảy máu theo Shinozaki và CS [1]

\begin{tabular}{|c|c|c|}
\hline Tổn thương & $\begin{array}{c}\text { Nguyên nhân } \\
\text { XHTH xác định }\end{array}$ & $\begin{array}{c}\text { Nguyên nhân } \\
\text { không chắc } \\
\text { chăn }\end{array}$ \\
\hline $\begin{array}{c}\text { Bất } \\
\text { thương } \\
\text { mạch máu }\end{array}$ & $\begin{array}{c}\text { Loại } 1 \mathrm{~B} \text {, typ 2, typ } \\
\text { 3 và } 4 \text { theo phân } \\
\text { loại YANO }\end{array}$ & $\begin{array}{c}\text { Loại } 1 \mathrm{~A} \text { không } \\
\text { chảy máu }\end{array}$ \\
\hline $\begin{array}{c}\text { U/ polyp } \\
\text { RN }\end{array}$ & $\begin{array}{c}\text { có loét bề mă̆t, có } \\
\text { tăng sinh mạch }\end{array}$ & $\begin{array}{c}\text { u }<\text { cm không } \\
\text { có loét bề măt }\end{array}$ \\
\hline Túi thữa RN & có loét & Không thấy loét \\
\hline Loét RN & Đường kính $\geq 1 \mathrm{~cm}$ & $\begin{array}{c}\text { Đường kính } \\
1 \mathrm{~cm}\end{array}$ \\
\hline
\end{tabular}

Tiêu chuẩn loại trừ: BN không đáp ứng tiêu chuẩn chẩn đoán nguyên nhân XHTH xác định của Shinozaki và $\mathrm{CS}$, nhiễm giun móc, loạn sản bạch mạch, viêm trợt sẽ không lấy vào đối tượng nghiên cứu.

Địa điểm và thời gian nghiên cứu: khoa Tiêu hoá, Bệnh viện Bạch Mai, Hà Nội, trong thời gian từ tháng 5 năm 2015 đến tháng 5 năm 2020.

Phương pháp nghiên cứu: nghiên cứu mô tả tiến cứu. Vì là bệnh lý hiếm gặp do đó chúng tôi tiến hành phương pháp chọn mấu thuận tiện.

\section{Quy trình nghiên cứu}

- BN chẩn đoán XHTH nghi tại RN sẽ được khai thác bệnh sử, khám lâm sàng theo bệnh án mẫu, làm xét nghiệm máu và chụp cắt lớp vi tính (CLVT) trong lúc chờ chuẩn bị NSRNBK. BN nếu NS dạ dày hoặc đại tràng thấy máu đỏ chảy từ RN thì có thể làm NSRNBK luôn, không cần chụp CLVT.

- BN được hồi sức, bù dịch, bù máu để duy trì hemoglobin máu khoảng $70-80 \mathrm{~g} /$ lít (nếu BN > 60 tuổi, có bệnh lý tim mạch sẽ duy trì ở mức 90 $-100 \mathrm{~g} /$ lít).

- BN được NSRNBK, thông thường đường miệng trước, trừ khi đại tiện phân máu đỏ và CLVT chỉ điểm tổn thướng đoạn cuối hồi tràng thì soi đường hậu môn trước. Nếu NSRNBK 1 đường không phát hiện nguyên nhân hoặc phát hiện bệnh lý có thể có nhiều tổn thương thì sẽ soi đường còn lại.

- BN sau khi phát hiện nguyên nhân XHTH sẽđược xử trí phẫu thuật, can thiệp nội soi hoặc điều trị nội khoa tuỳ thuộc tổn thương gây bệnh.

Xử lý số liệu. Số liệu được nhập bằng phần mềm EPIDATA và được xử lý bằng phần mềm SPSS 21 với thuật toán kiểm định $X 2$ cho biến định tính, kiểm định $T$ test và One-way INOVA test cho các biến định lượng. Sự khác biệt là có ý nghĩa thống kê khi $p<0,05$.

Khía cạnh đạo đức của đề tài. Nghiên cứu được chấp thuận bởi Hội đồng đạo đức trong Nghiên cứu Y sinh học của Đại học Y Hà Nội (QĐ số 187/HĐĐĐĐHYHN).

\section{KẾT QUẢ NGHIÊN CỨU}

3.1 Đặc điểm tuổi, giới các BN nghiên cứu. Trong thời gian từ 05/2015 đến 05/2020, nghiên cứu thu thập được 84 BN gồm 55 BN nam và $29 \mathrm{BN}$ nữ, tỷ lệ nam/nữ là 1,96/1. Tuổi trung bình $\mathrm{BN}$ là $49 \pm 18,9$ tuổi, trong đó $\mathrm{BN}$ trẻ nhất là 15 tuổi và $B N$ cao tuổi nhất là 83 tuổi.

Bảng 1: Phân bố nhóm tuổi và tuổi trung bình BN theo giới

\begin{tabular}{|c|c|c|c|c|c|}
\hline \multirow{2}{*}{ Tuổi } & \multicolumn{2}{|c|}{ Nam giới } & \multicolumn{2}{|c|}{ Nữ qiới } & \multirow[b]{2}{*}{$\mathbf{P}$} \\
\hline & $\mathbf{N}$ & $\%$ & $\mathbf{N}$ & $\%$ & \\
\hline$\leq 40$ & 27 & 49,1 & 6 & 20,7 & \multirow{4}{*}{$p=0,005$} \\
\hline $41-65$ & 21 & 38,2 & 11 & 37,9 & \\
\hline$>65$ & 7 & 12,7 & 12 & 41,4 & \\
\hline Tống & 55 & 100 & 29 & 100 & \\
\hline Trung bình & $44=$ & 18,5 & $58 \pm$ & 16,4 & $p=0,001$ \\
\hline
\end{tabular}

Nhận xét: Có sự khác biệt về tuổi trung bình giữa $B N$ nam giới và nữ giới $(p=0,001)$. Ớ nam giới, tuổi $\leq 40$ chiếm tỷ lệ cao nhất là $49,1 \%$, 41 - 65 tuổi là $38,2 \%$ và > 65 tuổi là $12,7 \%$ cònở nữ giới thì phân bố ngược lại, tỷ lệ tương ứng là $20,7 \%, 37,9 \%$ và $41,4 \%$, sự khác biệt là có ý nghĩa thống kê $(p=0,005)$.

\subsection{Tiền sử và triệu chứng lâm sàng}

Về tiền sử bệnh lý: có $13,1 \% \mathrm{BN}$ có tiên sử XHTH trên hoặc dưới và $39,3 \%$ có ít nhất 1 lần XHTH không xác định được nguyên nhân chảy máu. 35,7\% BN mắc các bệnh lý mạn tính (tăng huyết áp, suy tim, rung nhĩ, suy thận mạn, đái tháo đường, bệnh Won Willebrand, thoái khớp...) và $7,1 \%$ có dùng thuốc NSAIDs hoặc chống đông.

Bảng 2: triệu chứng lâm sàng nhóm BN nghiên cứu( $n=84)$

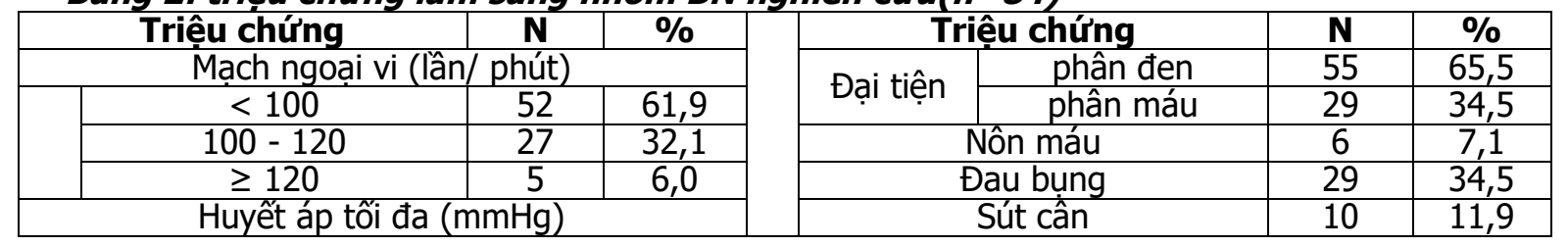


VIETNAM MEDICAL JOURNAL N01 - OCTOBER - 2021

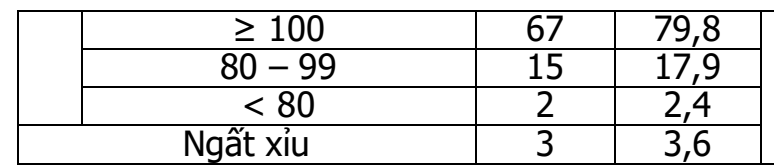

\begin{tabular}{|c|c|c|}
\hline Sốt & 4 & 4,8 \\
\hline Sờ thấy u trong ố bụng & 3 & 3,6 \\
\hline Chướng bụng & 1 & 1,2 \\
\hline & & \\
\hline
\end{tabular}

Nhận xét: Về tính chất phân, tỷ lệ BN đại tiện phân đen là 65,5\%, phân máu là 34,5\%. Có $38,1 \%$ BN có mạch > 100 lân/phút và 20,3\% BN có huyết áp < 100mmHg.

\subsection{Nguyên nhân XHTH tai RN phát hiên bằng NSRNBK}

\section{Bảng 3: Nguyên nhân XHTH tại RN và phân bố theo tuổi, giới}

\begin{tabular}{|c|c|c|c|c|c|c|c|}
\hline \multirow{2}{*}{ Nguyên nhân XHTH } & \multicolumn{2}{|c|}{ Tống } & \multicolumn{2}{c|}{ Giới (n) } & \multicolumn{3}{c|}{ Độ tuối } \\
\cline { 2 - 9 } & $\mathbf{N}$ & $\mathbf{0}$ & $\mathbf{N a m}$ & $\mathbf{N u \tilde { r }}$ & $\leq \mathbf{4 0}$ & $\mathbf{4 0 - 6 5}$ & $>\mathbf{6 5}$ \\
\hline Bất thường mạch máu & 20 & 23,8 & 13 & 7 & 5 & 7 & 8 \\
\hline Loét & 9 & 10,7 & 7 & 2 & 3 & 5 & 1 \\
\hline Túi thừa & 25 & & 21 & 4 & 16 & 6 & 3 \\
Meckel & 19 & 29,8 & 17 & 2 & 16 & 3 & 0 \\
Không Meckel & 6 & & 4 & 2 & 0 & 3 & 3 \\
\hline Khối u/ polyp & 30 & 35,7 & 14 & 16 & 9 & 14 & 7 \\
\hline Tống & $\mathbf{8 4}$ & $\mathbf{1 0 0}$ & $\mathbf{5 5}$ & $\mathbf{2 9}$ & $\mathbf{3 3}$ & $\mathbf{3 2}$ & $\mathbf{1 9}$ \\
\hline P & \multicolumn{3}{|c|}{$\mathbf{p = 0 , 0 2 8}$} & \multicolumn{3}{|c|}{ p=0,062 } \\
\hline
\end{tabular}
2 giới.

Nhân xét; có sự khác biệt có ý nghĩa thống kê $(p=0,028)$ về nguyên nhân thường găp nhất giữa

Bảng 4: tính chất phân và vị trí nguyên nhân XHTH tại RN

\begin{tabular}{|c|c|c|c|c|}
\hline \multirow{2}{*}{ Tính chất phân } & \multirow{2}{*}{ Tổng } & \multicolumn{3}{|c|}{ Vị trí nguyên nhân XHTH } \\
\cline { 3 - 5 } & & Tá-hông tràng * & Hồi tràng & Nhiều vị trí \\
\hline Phân đen & 55 & 39 & 14 & 2 \\
\hline Phân máu & 29 & 11 & 17 & $\mathbf{3}$ \\
\hline Tống & $\mathbf{8 4}$ & $\mathbf{5 0}$ & $\mathbf{3 1}$ \\
\hline P & \multicolumn{3}{|c|}{$\mathbf{P}=\mathbf{0 , 0 0 5}$} \\
\hline
\end{tabular}

*Tổn thương tá tràng được tính từ đoạn III, IV tá tràng

Nhận xét: Có sự khác biệt có ý nghĩa thống kê về vị trí nguyên nhân gây XHTH theo tính chất phân.

3.4 Mức độ thiếu máu trên xét nghiệm

Bảng 5: mức độ thiêu máu trên xét nghiệm huyết học $(n=84)$

\begin{tabular}{|c|c|c|c|c|c|c|c|c|c|}
\hline Giá trị & \multicolumn{3}{|c|}{ Số lượng hồng câu } & \multicolumn{3}{|c|}{ Hematocit } & \multicolumn{3}{|c|}{ Huyết sắc tố } \\
\hline Trung bình & \multicolumn{3}{|c|}{$2,68 \pm 0,69(\mathrm{~T} / \mathrm{I})$} & \multicolumn{3}{|c|}{$0,226 \pm 0,052$} & \multicolumn{3}{|c|}{$74,2 \pm 17,4(\mathrm{~g} / \mathrm{l})$} \\
\hline Thấp-cao nhất & \multicolumn{3}{|c|}{$[1,46-4,32]$} & \multicolumn{3}{|c|}{$[0,123-0,367]$} & \multicolumn{3}{|c|}{$[39,0-123,0]$} \\
\hline \multirow{5}{*}{$\begin{array}{l}\text { Phân nhóm } \\
\text { theo mức độ } \\
\text { nặng }\end{array}$} & & $\mathbf{N}$ & $\%$ & & $\mathbf{N}$ & $\%$ & & $\mathbf{N}$ & $\%$ \\
\hline & $\leq 2 \mathrm{~T} / \mathrm{l}$ & 16 & 19,1 & $\leq 0,2$ & 33 & 39,3 & $\leq 70 \mathrm{~g} / \mathrm{l}$ & 37 & 44,0 \\
\hline & $2-3 \mathrm{~T} / \mathrm{I}$ & 40 & 47,6 & $0,2-0,3$ & 46 & 54,8 & $71-90 \mathrm{~g} / \mathrm{l}$ & 32 & 38,1 \\
\hline & $>3 \mathrm{~T} / \mathrm{l}$ & 28 & 33,3 & $\geq 0,3$ & 5 & 5,9 & $>90 \mathrm{~g} / \mathrm{l}$ & 15 & 17,9 \\
\hline & Tống & 84 & 100 & Tống & 84 & 100 & Tống & 84 & 100 \\
\hline
\end{tabular}

Nhânn xét: tỷ lệ BN có mất máu mức độ nặng (Hematocrit $\leq 0,2$ ) là 39,3\% và mức độ trung bình (Hematocrit từ 0,2-0,3) là 54,8\%.

Có 30 BN phải truyền khối hồng câuu ở tuyến dưới với số lượng trung bình $1485 \pm 1583 \mathrm{ml}$, trung vị là 875 với IQR (500-2500). Tại Bệnh viện Bạch Mai, có 68 BN phải truyền khối hồng câuu với số lượng trung bình $1701 \pm 1425$, trung vị là 1375 với IQR (700-2100). Có 6 BN truyền huyết tương tươi đông lạnh, 3 BN truyền khối tiểu câu và 2 BN truyên tủa lạnh yếu tố VIII.

\subsection{Các xét nghiệm khác}

Bảng 6: các xét nghiệm khác của BN nghiên cứu (n=84)

\begin{tabular}{|c|c|c|c|}
\hline Loại xét nghiệm & Trung vị (IQR) & Loại xét nghiệm & Trung vị (IQR) \\
\hline INR & $1,07(1,02-1,15)$ & Üre (mmol/l) & $5,25(3,8-7,6)$ \\
\hline APTT bệnh/ chứng & $0,93(0,86-1,02)$ & Creatinin $(\cdot \mathrm{mol} / \mathrm{l})$ & $73,5(61,0-87,8)$ \\
\hline GOT (UI/I) & $21,3(15,0-26,5)$ & Glucose $(\mathrm{mmol} / \mathrm{l})$ & $6,3(5,5-7,9)$ \\
\hline GPT (UI/l) & $15,2(11,1-23,2)$ & & \\
\hline
\end{tabular}

Nhận xét: các xét nghiệm chức năng gan, thận, INR và APTT của BN có giá trị trung vị nằm trong giới hạn bình thường. 
3.6 Các bất thường phát hiện trên chụp cắt lớp vi tính (CLVT). Có 80/84 BN được chụp CLVT, trong đó 64/80 BN chụp CLVT > 64 dãy mạch ổ bụng, 12/80 BN chụp CLVT ruột non và 5/80 BN chụp CLVT ổ bụng thường.

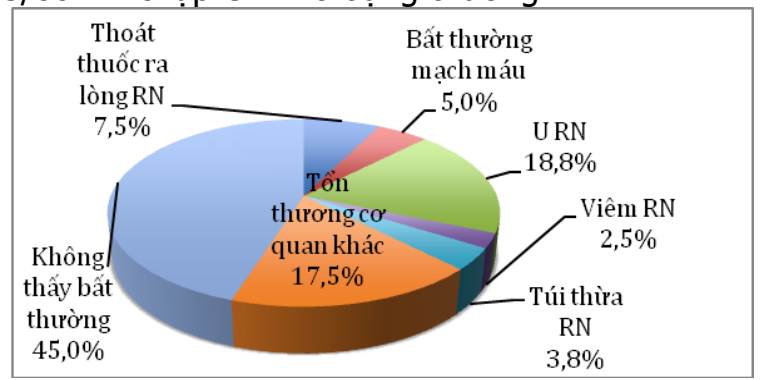

Biểu đồ: các bât thường phát hiện trên chup MSCT $(n=80)$

\section{BÀN LUÂ̂N}

Nghiên cứu chúng tôi thây XHTH tại RN có thể gặp ở mọi lứa tuổi, với tuổi trung bình nhóm BN nghiên cứu là $49 \pm 18,9$ tuổi, trẻ nhất là 15 tuổi và già nhất là 83 tuổi. Kết quả của chúng tôi cũng tương tự 2 nghiên cứu trong nước như của Nguyễn Công Long và CS là 46,4 tuổi[2]. Các nghiên cứu ở Trung Quốc thấy tuổi trung bình BN từ 43,5 đến 47 tuổi [3],[4],[5]. Nghiên cứu chúng tôi có $55 \mathrm{BN}$ nam $(65,5 \%)$ và $28 \mathrm{BN}$ nữ $(34,5 \%)$, tỷ lệ nam/ nữ $=1,96 / 1$. Nghiên cứu của Đỗ Anh Giang và CS thấy tỳ lệ nam/ nữ là 1,8 [6]. Hai nghiên cứu ở Trung Quốc thấy tỷ lệ tương tự, tỷ lệ BN nam trong nghiên cứu của Jiang và $C S$ là $63,9 \%$ và nghiên cứu Yin và $C S$ là $66,8 \%$ [3],[4].

Về phân bố theo nhóm tuổi trẻ ( $\leq 40$ tuổi), trung niên ( $41-65$ tuổi) và già ( $>65$ tuổi), tỷ lế tương ứng ở $\mathrm{BN}$ nam giới trong nghiên cứu này là $49,1 \% ; 38,2 \%$ và $12,7 \%$. Ở nữ giới thì có phân bố ngược lại, tỷ lệ tương ứng là 20,7\%; $37,9 \%$ và $41,4 \%$, khác biệt có ý nghĩa thống kê (Bảng ). Điều này được giải thích do sự khác biệt về nguyên nhân gây XHTH. Ở nam giới, nguyển nhân thường gặp nhất là túi thừa $(38,2 \%$, trong đó $17 / 21 \mathrm{BN}(81,0 \%)$ là túi thừa bẩm sinh Meckel), khối u $(25,8 \%)$ và bất thường mạch máu $(23,6 \%)$; còn ở nữ giới là khối u $(55,2 \%)$ và bất thường mạch máu $(24,1 \%)$, nguyên nhân túi thừa lại ít gặp $(13,8 \%)$, sự khác biệt là có ý nghĩa thống kê. Nghiên cứu của Jiang và CS thây tỷ lệ nguyên nhân u ở nữ giới cao hơn so với nam giới $(69,2 \%$ và $52,2 \%)$ [3]. Theo nhóm tuổi, nguyên nhân thường gặp ở tuổi $\leq 40$ là túi thừa $(48,5 \%$, trong đó $100 \%$ là túi thừa Meckel) và u/ polyp (27,3\%), ở 40 - 65 tuổi là u/ polyp $(43,8 \%)$ và bất thường mạch máu $(21,9 \%)$ còn ở> 65 tuổi là bất thường mạch máu $(42,1 \%)$ và u/polyp $(36,8 \%)$, tuy nhiênsự khác biệt này là chưa đủ có ý nghĩa thống kê $(p=0,062)$, có thể do cõ̃ mẫu còn nhỏ. Nghiên cứu của Zhang và cộng sự với cõ̃ mẫu lớn hơn ( $n=385)$ thấy ở $B N>$ 65 tuổi, tỷ lệ bất thường mạch máu là $54,35 \%$, loét RN là 13,04\%, khối u RN là 11,96\%; ở người từ 40 - 65 tuổi, bất thường mạch máu là $34,82 \%$, u RN là $31,25 \%$, viêm ruột là $9,82 \%$ và ở người trẻ < 40 tuổi, bệnh Crohn là nguyên nhân thường gặp nhất 34,55\%, khối u RN là $23,64 \%$ và viêm ruột là $10,91 \%$ [7].

Về tiền sử bệnh, nghiên cứu thây $39,3 \% \mathrm{BN}$ đã từng bị ít nhất 1 lần XHTH chưa rõ nguyên nhân. Nghiên cứu của Nguyễn Công Long và CS thấy $41 \%$ BN chảy máu tái phát nhiều lần [2]. Đỗ Anh Giang và CS thấy 46,4\% BN có tiền sử ít nhất 1 lần XHTH chưa rõ nguyên nhân [6]. Khi chưa có NSRN, thông thường BN XHTH đại thể sau khi được NS dạ dày, đại tràng và chụp CLVT mà không thấy nguyên nhân, nếu đã tự cầm chảy máu sẽ được điều trị nội khoa mà không phẫu thuật thăm dò. Do đó, BN có thể tái phát XHTH nhiều lần. Có $35,7 \%$ BN có bệnh lý mạn tính như bệnh tim mạch (tăng huyết áp, suy tim, rung nhĩ), suy thận mạn ... và $7,1 \% \mathrm{BN}$ sử dụng thuốc chống đông hoặc NSAIDs, Aspirin liều thấp. Nghiên cứu của Yin và CS thãy $42,6 \%$ BN có bệnh lý mạn tính và $26,8 \%$ BN có sử dụng thuốc chống đông hoặc NSAIDs [4]. Một số bệnh lý mạn tính như suy tim, xơ gan, suy thận sẽ gây giảm tưới máu RN, tạo cơ hội hình thành loạn sản mạch ở người lớn tuổi, trong khi các bệnh lý khác như van tim nhân tạo, bệnh Won Willebrand hoặc dùng thuốc chống đông và NSAIDs sẽ làm cho tổn thương loạn sản mạch dễ chảy máu.

Về tính chất phân, $65,5 \%$ BN có đại tiện phân đen và $34,5 \%$ BN có phân máu. Nghiên cứu của Jiang và CS thây triệu chứng phân đen là $62,7 \%$ vàphân máu là $35,9 \%$, tương tự nghiên cứu chúng tôi[3]. Dấu hiệu phân đen là một điểm lưu ý giúp xác định vị trí tổn thương gây chảy máu. Chúng tôi thấy BN có đại tiện phân đen thì tổn thương nằm ởđoạn cao RN (đoạn III, IV tá tràng và hỗng tràng) là $70,9 \%$, khác biệt có ý nghĩa với $B N$ đại tiện phân máu $(37,9 \% ; p=0,005)$. Nghiên cứu của Zhu và CS thây BN có đại tiện phân đen thì tỷ lệ gặp tổn thương nằm ở đoạn cao RN là $56,1 \%$ so với BN không đại tiện phẩn đen là $34,8 \%(p<0,001)$ [8]. Các kết quả cho thấy với $\mathrm{BN}$ có đại tiện phân đen nên lựa chọn NSRNBK đường miệng.

Biểu hiện lâm sàng của mất máu cấp tính là thay đổi của mạch và huyết áp ngoại vi. Trong 
nghiên cứu này, tỷ lệ $B N$ có mạch nhanh $(\geq 100$ lần/ phút) là $38,1 \%$, trong đó mạch rất nhanh ( $\geq$ 120 lần/phút) là $6,0 \%$. Về huyết áp tối đa, $17,9 \%$ BN ở mức giới hạn thấp $(80-99 \mathrm{mmHg})$ và $2,4 \% \mathrm{BN}$ có $\mathrm{HA}$ rất thấp $(<80 \mathrm{mmHg})$. Như vậy, trên lâm sàng tỷ lệ $B N$ mất máu cấp tính mức độ vừavà nặng là $38,1 \%$, đây là các $\mathrm{BN}$ cần hồi sức nhanh chóng,bù dịch và máu để bồi phụ thể tích tuần hoàn đã bi mất.

Nghiên cứu thấy $34,5 \%$ BN có đau bung. Hai nghiên cứu ở Việt Nam, như của Nguyễn Công Long và $C S$ thây $12 \%$ BN có đau bụng và của Đố Anh Giang là 33,9\% BN [2],[6]. Tỷ lệ này trong nghiên cứu của Jiang và CS ở Trung Quốc là 34,3\%[3]. Triệu chứng đau bụng thường gợi ý sự xâm lấn RN do u hoăc viêm. Nghiên cứu chúng tôi có $3,6 \%$ BN có sờ thấy u trong ổ bụng. Nghiên cứu của Nguyễn Công Long và $C S$ với $77 \%$ XHTH do u RN thì không có $B N$ nào sờ thấy u trong ổ bụng [2]. VìRN di động nên các khối u có trọng lượng lớn nên thường rơi xuống tiểu khung, do đó khó sờ thấy. Các triệu chứng khác như sút cân, chướng bụng... gặp với tỷ lệ thấp. Nhìn chung, các tác giả đều nhận xét là biểu hiện lâm sàng của $\mathrm{XHTH}$ tại RN khá nghèo nàn ngoại trừ triệu chứng chảy máu tiêu hoá râm rộ và nặng [2].

Về xét nghiêm, thiếu máu cấp tính thường được đánh giá bằng chỉ số hematocrit và nồng độ hemoglobin. Ớ giai đoạn đầu, hematocrit và hemoglobin vẫn có thể bình thường vì $\mathrm{BN}$ mất máu toàn bộ, sau đó sẽ giảm dần khi huyết thanh được bù lại do vận chuyển nước ở khoang gian bào vào lòng mạch hoặc do $\mathrm{BN}$ được truyền dịch. Vì vậy, ở giai đoạn đầu, đánh giá mức độ chảy máu thì dựa vào lâm sàng còn sau 24 h thì dưa vào xét nghiệm sẽ chính xác hơn. Nghiên cứu chúng tôi thấy tỷ lệ $\mathrm{BN}$ có hematocrit $\leq 0,3$ là $94,1 \%$ và hemoglobin $<90 \mathrm{~g} / \mathrm{l}$ là $82,1 \%$. Tỷ lệ $B N$ có mức độ thiếu máu vừa và nặng trên xét nghiệm cao hơn khi đánh giá trên lâm sàng $(38,1 \%)$ là do chúng tôi ghi nhận giá trị thấp nhất của xét nghiệm này theo thời gian, sau khi BN đã được truyền dịch bồi phu thể tích tuần hoàn. Lượng hemoglobin trung bình trong nghiên cứu chúng tôi là $74,2 \pm 17,4 \mathrm{~g} / \mathrm{l}$, cao hơn so với nghiên cứu của Nguyễn Công Long và CS là $65,7 \pm 21,3 \mathrm{~g} / \mathrm{l}$ [2]. Nghiên cứu chúng tôi có $44,0 \%$ BN có hemoglobin < 70G/I - đây là giới han cần phải truyền khối hồng cầu theo hướng dẫn xử trí XHTH trên và $38,1 \% \quad B N$ có hemoglobin từ $70-90 \mathrm{G} / \mathrm{l}_{\mathrm{L}}$ là mức có thể truyền máu nếu lâm sàng $B N$ vấn còn tình trạngthiếu oxy mô, rối loạn huyết động, tình trạng chảy máu chưa kiểm soát được hoặc $\mathrm{BN}$ có tiên sử bệnh lý tim mạch... Trong 84 BN của nghiên cứu, có $35,7 \%$ BN phải truyên khối hồng cầu ở tuyến dưới và $81,0 \%$ BN phải truyền khối hồng cầu ở BV Bạch Mai với số lượng trung bình là $1701 \pm$ $1425 \mathrm{ml}$. Nghiên cứu của Yin và CS có $81,5 \% \mathrm{BN}$ phải truyền máu [4]. Shinozaki và CS ở nhóm BN chảy máu đại thể có $65,9 \%$ BN phải truyền máu với số lượng truyền máu trung bình là 8,1 đơn vị cho các $B N$ đang chảy máu tiến triển và 4,2 đơn vị cho $\mathrm{BN}$ đã cầm chảy máu [1].

Về chup CLVT, nghiên cứu chúng tôi thấy tỷ lệ phát hiện bất thường tại RN là 37,5\%. Phân tích gộp của Wang và CS so sánh thấy khả năng chẩn đoán XHTH tại RN của CLVT RN thấp hơn NSRNBK (38\% và $78 \%)$ [9]. NSRNBK có ưu thế rõ rệt hơn trong chẩn đoán các tổn thương viêm, loạn sản mạch và túi thừa $\mathrm{RN}$. Vì vậy, ở các $\mathrm{BN}$ mà CLVT bụng không thấy hoặc không phân biệt được các tổn thương gây XHTH, NSRNBK là lựa chọn thích hợp để tiếp cận chẩn đoán.

\section{KẾT LUÂ̂N}

Trong số 84 BN XHTH tại RN, 39,3\% có tiền sử XHTH không rõ nguyên nhân, $35,7 \%$ mắc bệnh mạn tính và $7,1 \%$ dùng thuốc chống đông/ NSAIDs. Tỷ lệ BN đại tiện phân đen có nguyên nhân chảy máu nằm ở đoạn cao RN là $70,9 \%$, cao hơn so với phân máu là $37,9 \%$. 37,5\% phát hiện bất thường ruột non trên CLVT. 82,1\% BN thiếu máu mức độ vừa và nặng trên xét nghiệm và $81,0 \%$ BN phải truyền khối hồng cầu.

\section{TÀI LIÊU THAM KHẢO}

1. S. Shinozaki, H. Yamamoto, T. Yano et al (2010). Long-term outcome of patients with obscure gastrointestinal bleeding investigated by double-balloon endoscopy. Clin Gastroenterol Hepatôl, 8(2), 151-8.

2. Nguyễn Cống Long, Bùi Xuân Trường, Nguyễn Thị Vần Hồng et al (2009). Đắc điếm lâm sàng và cận lâm sàng xuất huyết tiêu hoá nguyên nhân từ ruột non. Tạp chí khoa học Tiêu hoá Việt Nam, IV(16), 1069 - 1074.

3. D. L. Jiang, H. Y. Liu, Y. Yuan et al (2012). Analysis of the causes and clinical characteristics of jejunoileal hemorrhage in China: a multicenter 10 year retrospective survey. BMC Gastroenterol, 12, 101.

4. A. Yin, L. Zhao, Y. Ding et al (2020). Emergent Double Balloon Enteroscopy in Overt Suspected Small Bowel Bleeding: Diagnosis and Therapy. Med Sci Monit, 26, e920555.

5. M. C. Ba, S. H. Qing, X. C. Huang et al (2006). Diagnosis and treatment of small intestinal bleeding: retrospective analysis of 76 cases. World J Gastroenterol, 12(45), 7371-4.

6. Đố Anh Giang, Kiêu Văn Tuấn, Nguyễn Mạnh Trường et al (2014). Hiệu quả chẩn đoán và điều trị chảy máu tiêu hoá ruột non bằng nội soi 
ruột non bóng đơn Tap chí khoa học Tiêu hoá Việt Nam, IX(37), 2447 - 2454.

7. B. L. Zhang, C. X. Chen and Y. M. Li (2012) Capsule endoscopy examination identifies different leading causes of obscure gastrointestinal bleeding in patients of different ages. Turk J Gastroenterol, 23(3), 220-5.
8. C. N. Zhu, J. Friedland, B. Yan et al (2018). Presence of Melena in Obscure Gastrointestinal Bleeding Predicts Bleeding in the Proximal Small Intestine. Dig Dis Sci, 63(5), 1280-1285.

9. Z. Wang, J. Q. Chen, J. L. Liu et al (2013). CT enterography in obscure gastrointestinal bleeding: a systematic review and meta-analysis. J Med Imaging Radiat Oncol, 57(3), 263-73.

\title{
NGHIÊN CỨU ÁP DỤNG CHỌC HÚT BẰNG KIM NHỎ DƯớI HƯớNG DẪN SIÊU ÂM TRONG CHẨN ĐOÁN MộT Số TỔN THƯƠNG KHU TRÚ Ở TỰ
}

\author{
Nguyễn Thu Lan*, Nguyễn Thái Bình**, Nguyễn Ngọc Cương **, \\ Đào Thị Luận**, Bùi Văn Lệnh**
}

\section{TÓM TẮT}

Việc xác định đúng bản chất giải phẫu bệnh của tổn thương khu trú của tụy là vố cùng quan trọng, quyết đinh thái đô điều tri. Có nhiêu phương pháp để lấy bệnh phẩm tụy như chọc hút kim nhỏ dưới hướng dần của siêu âm $(S A)$, siêu âm nôi soi (SANS), sinh thiết tụy trong phẩu thuật, sinh thiết tụy dưới hướng dẫn SÄ, cắt lớp vi tính (CLVT). Chúng tôi nghiên cứu 18 bệnh nhân $(\mathrm{BN})$ có tổn thương khu trú ở tụy và được choc hút tế bào bằng kim nhỏ dưới hướng dẫn siêu âm. Kết quả: số lân chọc hút trung bình 1,4 lần/BN. 17/18 bệnh nhân không đau trong quá trình làm thủ thuật. Độ nhạy, độ đặc hiệu, giá trị dự báo dương tính, giá trị dự báo âm tính, độ chẩn đoán chính xác của phương pháp chọc hút tế bào bằng kim nhỏ dưới siêu âm trong chẩn đoán ung thư tụy lần lượt là $90,9 \%, 100 \%, 100 \%, 87,5 \%$ và $94,4 \%$. $100 \%$ không có biên chứng sau thủ thuật. Kết luận: Chọc hút tế bào bằng kim nhỏ dưới hướng dấn siều âm là phương phá an toàn, hiệu quả cao để chẩn đoán tổn thương khu trú ở tụy, đặc biête là ung thư tụy.

Từ khóa: tổn thương khu trú của tụy, chọc hút kim nhỏ, siêu âm, ung thư tụy.

\section{SUMMARY}

\section{VALUE OF ULTRASOUND-GUIDED FINE NEEDLE ASPIRATION IN DIAGNOSIS OF FOCAL PANCREATIC LESIONS}

Confirmation of the nature of focal pancreatic lesions plays a pivotal role in treatment. There are many different types of sampling procedures such as ultrasound-guided fine needle aspiration (US FNA), endoscopic ultrasound-guided fine needle aspiration (EUS FNA), surgical biopsy, ultrasound guided biopsy and computed tomography. We reviewed 18 consecutive ultrasound-guided fine-needle aspiration

\footnotetext{
*Trường Đai hoc Y Hà Nôi

**Bênh viền Đai hoc Y Hà Nôi

Chịu trách nhiệm chính: Nguyễn Thu Lan

Email: nguyenthulan16051995@gmail.com

Ngày nhận bài: 5.7.2021

Ngày phản biên khoa hoc: 30.8.2021

Ngày duyệt bài: 7.9.2021
}

cytological sampling procedures for focal pancreatic lesions. Result: median number of aspiration was 1.4 times/patient, painless was seen in 17/18 patients. Sensitivity, specificity, positive prediction value and negative prediction value of US FNA in diagnosis pancreatic cancer were $90.9 \%, 100 \%, 100 \%, 87.5 \%$ and $94.4 \%$, respectively. No complications related to US-FNA were noted. Conclusion: US FNA cytological sampling is safe and effective for the diagnosis and planning of management of focal pancreatic lesions, especially pancreatic cancer.

Key words: focal pancreatic lesions, US FNA, pancreatic cancer.

\section{I. ĐẶT VẤN ĐỀ}

Tổn thương khu trú của tụy ngày càng gia tăng do được phát hiện môt cách ngẫu nhiên ${ }^{1}$. Dựa trên bản chất giải phẩu bệnh, tổn thương khu trú của tụy được chia thành tổn thương lành tính, tổn thương tiền ung thư và ung thư. Việc xác định đúng bản chất giải phẫu bệnh của tổn thương là vô cùng quan trọng, quyết định đến thái độ điều trị tiếp theo. Chẩn đoán phân biệt các tổn thương khu trú của tụy có thể dựa vào lâm sàng, các phương pháp chẩn đoán hình ảnh như $S A, C L V T, C H T$, SANS và các xét nghiệm hóa sinh nhưng các phương pháp này chỉ gợi ý tính chất lành tính/ ác tính của tổn thương, không thể thay thế được giải phẫu bệnh. Chẩn đoán tễ bào học và mô bênh học giúp chúng ta biết bản chất khối khu trú ở tụy, giúp khẳng định chẩn đoán và có kế hoạch điều trị thích hợp. Có nhiều phương pháp để lấy bệnh phẩm tụy như chọc hút kim nhỏ dưới hướng dẫn của SA, SANS, sinh thiết tụy trong phẫu thuật, sinh thiết tụy dưới hướng dẫn SA,CLVT. Trong đó, chọc hút kim nhỏ tổn thương tụy dưới hướng dẫn siêu âm có các ưu điểm: kết quả chính xác cao, an toàn, chi phí thấp, không nhiễm xạ. Vì thế chọc hút kim nhỏ dưới hướng dẫn SA được xem là một kỹ thuât được ưu tiên lựa chọn trong chẩn đoán tổn 